\title{
Roles for $\mathrm{CCK}_{1}$ and $5-\mathrm{HT}_{3}$ receptors in the effects of $\mathrm{CCK}$ on presympathetic vasomotor neuronal discharge in the rat
}

\author{
${ }^{1,2}$ Mitsuhiko Saita \& *,1 Anthony J.M. Verberne \\ ${ }^{1}$ Department of Medicine, Clinical Pharmacology and Therapeutics Unit, Austin and Repatriation Medical Centre, University of \\ Melbourne, Heidelberg, Victoria 3084, Australia
}

\begin{abstract}
1 The role of peripheral 5-hydroxytryptamine $\left(5-\mathrm{HT}_{3}\right)$ receptors and cholecystokinin type $1\left(\mathrm{CCK}_{1}\right)$ receptors in the inhibitory effects of phenylbiguanide (PBG) and CCK on arterial blood pressure, heart rate and the discharge of presympathetic vasomotor neurones of the rostral ventrolateral medulla (RVLM) was studied in $\alpha$-chloralose-anaesthetized rats.

2 CCK ( 1 and $4 \mu \mathrm{g} \mathrm{kg}^{-1}$, i.v.) and PBG (2 and $10 \mu \mathrm{g} \mathrm{kg}^{-1}$, i.v.) reduced arterial blood pressure and heart rate, and inhibited the discharge of single RVLM presympathetic vasomotor neurones in a doserelated manner.

3 Devazepide $\left(0.5 \mathrm{mg} \mathrm{kg}^{-1}\right.$, i.v.), a selective $\mathrm{CCK}_{1}$ receptor antagonist, blocked the effects of CCK on arterial blood pressure, heart rate and neuronal discharge but did not significantly alter these responses to PBG. MDL72222 (0.1 $\mathrm{mg} \mathrm{kg}^{-1}$, i.v.), a selective $5-\mathrm{HT}_{3}$ receptor antagonist, blocked the effects of PBG on arterial blood pressure, heart rate and presympathetic neuronal discharge. MDL72222 attenuated the effects of CCK on arterial blood pressure, heart rate and RVLM presympathetic neuronal discharge. Vehicle did not significantly alter any of the responses to CCK or PBG.

4 These experiments suggest that systemically administered CCK acts directly through $\mathrm{CCK}_{1}$ receptors to modulate sympathetic vasomotor function. In addition, the actions of CCK also are partly dependent on activation of $5-\mathrm{HT}_{3}$ receptors. CCK may release 5-HT which then acts at 5- $\mathrm{HT}_{3}$ receptors to produce sympathetic vasomotor inhibition. In contrast, the actions of PBG are entirely dependent on $5-\mathrm{HT}_{3}$ receptors and are independent of any actions at the $\mathrm{CCK}_{1}$ receptor.

British Journal of Pharmacology (2003) 139, 415 - 423. doi:10.1038/sj.bjp.0705245
\end{abstract}

Keywords: Vagal afferent; sympathetic; rostral ventrolateral medulla

Abbreviations: CCK, cholecystokinin; 5-HT, 5-hydroxytryptamine; PBG, phenylbiguanide; RVLM, rostral ventrolateral medulla

\section{Introduction}

Vagal afferent nerves arise from a wide variety of structures within the abdominal viscera and the cardiopulmonary region (Berthoud \& Neuhuber, 2000). They sense a broad range of biological signals including local concentrations of gastrointestinal hormones, cytokines, sugars, lipids, monoamines or mechanical distortion of the structures which they innervate (Berthoud \& Neuhuber, 2000; Verberne et al., 2003). Activation of some of these chemosensitive vagal afferent pathways can have profound effects on the circulation by influencing sympathetic outflow to the vasculature and the heart. Agonists at the 5-hydroxytryptamine $\left(5-\mathrm{HT}_{3}\right)$ receptor such as phenylbiguanide (PBG) and 1-(m-chlorophenyl)-biguanide are powerful activators of the sympathoinhibitory reflex known as the von Bezold - Jarisch reflex (Kilpatrick et al., 1990; Verberne \& Guyenet, 1992). Inhibition of sympathetic vasomotor function produced by activation of the von Bezold - Jarisch is relatively uniform and occurs regardless of the type of vascular bed. Thus, activation of this reflex results in

*Author for correspondence; E-mail: antonius@unimelb.edu.au ${ }^{2}$ Present address: Department of Cardiovascular Control, Kochi Medical School, Nankoku, Kochi, Japan inhibition of renal, lumbar, splanchnic and adrenal sympathetic outflow and prominent hypotension (Veelken et al., 1990; Verberne \& Guyenet, 1992; Sevoz et al., 1996; Scrogin et al., 1998; Cao \& Morrison, 2000; Schreihofer \& Guyenet, 2000). The intramedullary pathway that mediates this reflex has been identified (Verberne \& Guyenet, 1992) and appears to be similar to the trisynaptic model described for the baroreflex pathway (Guyenet et al., 1987).

A key feature of the mechanism through which $5-\mathrm{HT}_{3}$ receptor agonists influence sympathetic vasomotor function is inhibition of the discharge of presympathetic vasomotor neurons of the rostral ventrolateral medulla (RVLM) (Verberne \& Guyenet, 1992; Vayssettes-Courchay et al., 1997; Verberne et al., 1999). In accord with the effects on sympathetic vasomotor outflow, activation of $5-\mathrm{HT}_{3}$ receptors uniformly inhibits the discharge of RVLM presympathetic neurons (Verberne et al., 1999; Sartor \& Verberne, 2002).

The gastrointestinal peptide cholecystokinin (CCK) is a potent activator of gastrointestinal vagal afferent nerve fibres (Blackshaw \& Grundy, 1990; Widdop et al., 1994; YoshidaYoneda et al., 1996; Kurosawa et al., 1997) and has selective effects on sympathetic vasomotor outflow (Sartor \& Verberne, 2002). CCK also selectively inhibits the discharge of a 
subpopulation of RVLM presympathetic neurons (Sartor \& Verberne, 2002) suggesting that its effects are mediated by a mechanism different to that of PBG. On the other hand, it has been suggested that some of the effects of CCK are mediated by release of 5-HT (Blackshaw \& Grundy, 1993; Daughters et al., 2001).

In this study, we have examined the selectivity of the inhibitory effects of PBG and CCK on RVLM presympathetic neuronal discharge and determined whether these effects occur exclusively through activation of $5-\mathrm{HT}_{3}$ receptors and $\mathrm{CCK}_{1}$ receptors, respectively.

\section{Methods}

All experiments were performed using male Sprague - Dawley rats $(250-380 \mathrm{~g})$ and were approved by the Ethical Review Committee of the Austin and Repatriation Medical Centre (Heidelberg, Victoria, Australia) and complied with the principles outlined in the Australian Code of Practice for the Care and Use of Animals for Scientific Purposes.

\section{General procedures}

Rats were tracheostomized after induction of anaesthesia produced by placement into a chamber saturated with halothane vapour (Fluothane ${ }^{\mathrm{TM}}$, Zeneca, Macclesfield, U.K. ). After cannulation of the trachea, all animals were ventilated artificially with $100 \% \mathrm{O}_{2}\left(1 \mathrm{ml} 100 \mathrm{~g}^{-1}\right.$ body weight, $40-60$ breaths $\min ^{-1}$ ) containing $1.3-1.5 \%$ halothane. The deep surgical level of anaesthesia produced by halothane was maintained throughout the entire surgical procedure where the absence of firm paw pinch and corneal probing responses were used to verify the depth of anaesthesia. Core temperature was maintained at $36-38^{\circ} \mathrm{C}$ using a servo-controlled heating. The left carotid artery and left jugular vein were cannulated to measure arterial blood pressure and heart rate and for intravenous drug administration, respectively.

After the completion of all surgery, the inspired halothane concentration was gradually reduced to zero and $\alpha$-chloralose ( $70 \mathrm{mg} \mathrm{kg}^{-1}$, i.v.) was administered slowly over a $20-30 \mathrm{~min}$ period. Once an appropriate level of anaesthesia was achieved, as ascertained by application of the tests described above, the paralysing agent pancuronium bromide $\left(1-2 \mathrm{mg} \mathrm{kg}^{-1}\right.$, i.v) was administered. After neuromuscular blockade was established, the stability of the arterial blood pressure and heart rate record and the absence of a pressor response to firm hindlimb toe pinch were used as indications of adequate anaesthesia. Supplements of $\alpha$-chloralose $\left(20-25 \mathrm{mg} \mathrm{kg}^{-1}\right.$, i.v.) were administered as needed according to the above criteria, or on an hourly basis. Adequacy of anaesthesia was also confirmed before administration of pancuronium supplements $(0.3-$ $0.5 \mathrm{mg} \mathrm{kg}^{-1}$ ). Pancuronium was supplemented hourly or as indicated by a muscle twitch response to spinal stimulation. Note that the pancuronium has detectable vagolytic actions and so reduces the bradycardic actions of PBG.

\section{Extracellular single unit recording}

In addition to the general procedures outlined above, an inflatable occlusive cuff was placed around the abdominal aorta just below the level of the diaphragm. This was used to produce a precisely controlled elevation of arterial blood pressure in order to stimulate the baroreceptors. Rats were then placed into a stereotaxic apparatus and the dorsal cerebellar surface was exposed by removal of a portion of the interparietal bone. A bipolar electrode was placed on the mandibular branch of the right facial nerve which, when stimulated $(0.1 \mathrm{~ms}$ pulses, $0.5 \mathrm{~Hz}, 0.3-1.0 \mathrm{~mA})$, produced an antidromic field potential within the facial motor nucleus of the ventral medulla. The magnitude of the field potential was used to identify the caudal, medial and ventral contours of the facial motor nucleus as previously described (Brown \& Guyenet, 1985; Verberne et al., 1999). A bipolar electrode was also placed into the dorsolateral funiculus of the thoracic spinal cord (T2-T3) enabling antidromic activation of spinally projecting, barosensitive neurons within the RVLM. Invariant antidromic latency and the collision test were used to establish the antidromic nature of spikes produced by spinal stimulation $(0.5 \mathrm{~Hz}, 0.5 \mathrm{~ms}$ duration, $0.3-2.5 \mathrm{~mA}$ intensity). Conduction velocities of spinal axons were calculated by dividing the straight-line distance between the recording electrode and the spinal stimulating electrode (in metres) by the antidromic latency (in seconds). Only barosensitive cells that were collision test positive were included in the study. Glass microelectrodes ( $2 \mathrm{~mm}$ OD) containing $0.5 \mathrm{M}$ sodium acetate and $2 \%$ Pontamine sky blue were used to record extracellularly from neurons in the RVLM. The signals were amplified $(\times 1000)$, filtered $(400-$ $4000 \mathrm{~Hz}$ ) and monitored using an oscilloscope and an audio amplifier. The effects of CCK (1 and $4 \mu \mathrm{g} \mathrm{kg}^{-1}$, i.v.) or PBG (2 and $10 \mu \mathrm{g} \mathrm{kg}^{-1}$, i.v.) on arterial blood pressure and the discharge rate of RVLM barosensitive, spinally projecting neurons were recorded and stored onto video tape together with the blood pressure responses. Neuronal discharge rates were measured at rest prior to manipulation of arterial blood pressure levels or injection of any drugs. A change in discharge rate was calculated by counting the total number of spikes over the period of the response and expressing this is as a percentage of the total number of spikes observed over a period of the same duration prior to drug administration.

The doses of CCK and PBG were submaximal and were chosen on the basis of previous reports (Verberne \& Guyenet, 1992; Verberne et al., 1999; Sartor \& Verberne, 2002).

Only one neuron was studied in each experiment. CCKsensitive RVLM presympathetic neurons are a subpopulation of the total population of spinally projecting, barosensitive cells in the RVLM (Sartor \& Verberne, 2002). These are usually neurons with spinal axonal conduction velocities in the lightly myelinated range. After confirmation of the identity of a CCK-sensitive RVLM presympathetic vasomotor neuron, doses of PBG (2 and $10 \mu \mathrm{g} \mathrm{kg}^{-1}$, i.v.) or CCK (1 and $4 \mu \mathrm{g} \mathrm{kg}^{-1}$, i.v.) were administered in random fashion. These were repeated after administration of the selective $\mathrm{CCK}_{1}$ receptor antagonist devazepide $\left(0.5 \mathrm{mg} \mathrm{kg}^{-1}\right.$, i.v.) (Louie et al., 1988) or the selective 5- $\mathrm{HT}_{3}$ receptor antagonist MDL72222 (0.1 $\mathrm{mg} \mathrm{kg}^{-1}$, i.v.) (Fozard, 1984) or a vehicle consisting of dimethyl sulphoxide/polyethyleneglycol $400(9: 1)$, diluted $1: 1$ with normal saline $\left(0.9 \% \mathrm{NaCl} \mathrm{w} \mathrm{v}^{-1}\right)$. In the vehicle experiments, after repeat administration of the agonists, devazepide $\left(0.5 \mathrm{mg} \mathrm{kg}^{-1}\right.$, i.v.) was administered followed by readministration of PBG $\left(10 \mu \mathrm{g} \mathrm{kg}^{-1}\right.$, i.v. $)$ and CCK $\left(4 \mu \mathrm{g} \mathrm{kg}^{-1}\right.$, i.v.). 


\section{Histological analysis of recording sites}

Recording sites within the RVLM were marked by ionophoretic deposition of Pontamine sky blue from the recording electrode. At the conclusion of each unit recording experiment, the animals were deeply anaesthetized with pentobarbitone sodium (Nembutal, Rhone Merieux Australia, Pinkenba, Queensland, Australia; $60 \mathrm{mg} \mathrm{kg}^{-1}$, i.p.) prior to transcardiac perfusion with $4 \%$ formaldehyde/Tris buffered saline $(0.05 \mathrm{M}, \mathrm{pH} 7.6)$ solution and the brains were collected for histological verification of recording sites. Brains were sectioned using a cryostat and mounted onto gelatin-subbed slides and were stained for Nissl substance using Cresyl violet. Recording sites were identified under the light microscope and were mapped onto standard maps of the rat brain with reference to a rat brain atlas (Paxinos \& Watson, 1997).
Data analysis and statistics Extracellular action potentials, arterial blood pressure, heart rate and stimulation pulses were recorded onto video tape using a PCM data acquisition system (Vetter Instruments, Rebersburg, PA, U.S.A.). Signals were analysed off-line using a Cambridge Electronic Design data acquisition system (CED, Cambridge, U.K.) and Spike2 software. Data are expressed as means \pm s.e.m. Percentage changes in neuronal discharge rate were calculated by counting the number of spikes occurring during the response to each agent and expressing this value as a percentage of the number of spikes occurring over the same period prior to administration of the test agent. Data are expressed as means \pm s.e.m. Differences between means were compared by one-way ANOVA followed by a Tukey-Kramer test. $P<0.05$ was considered as the level of significance. a

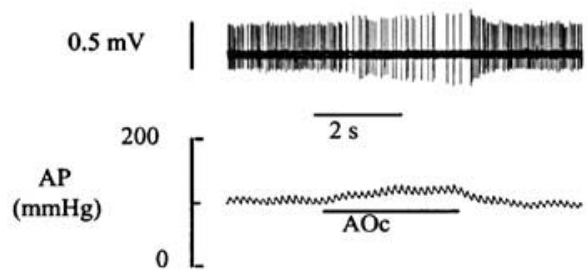

b

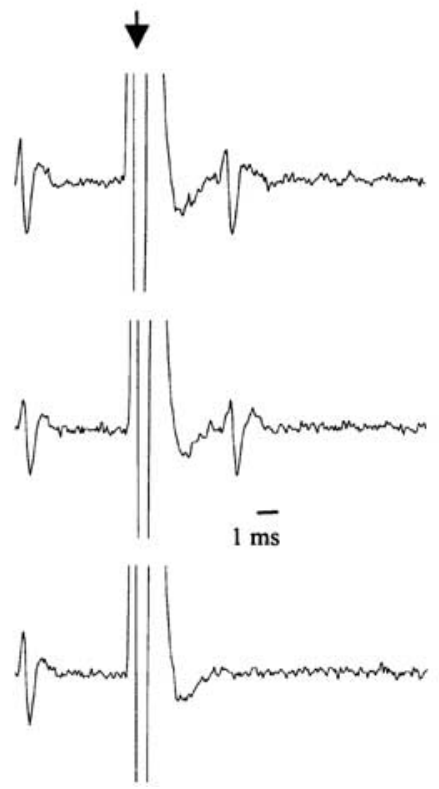

C

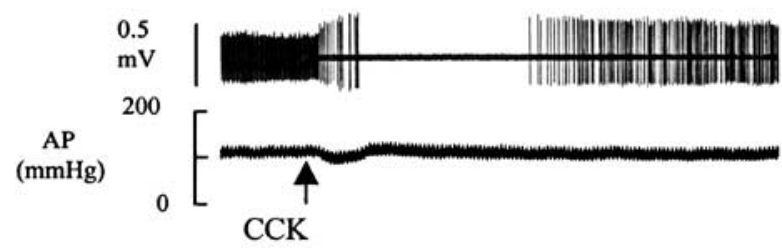

Post-devazepide

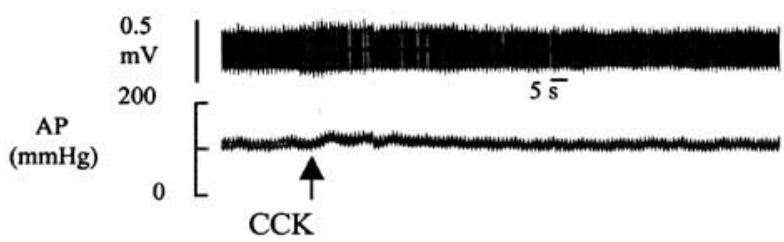

d

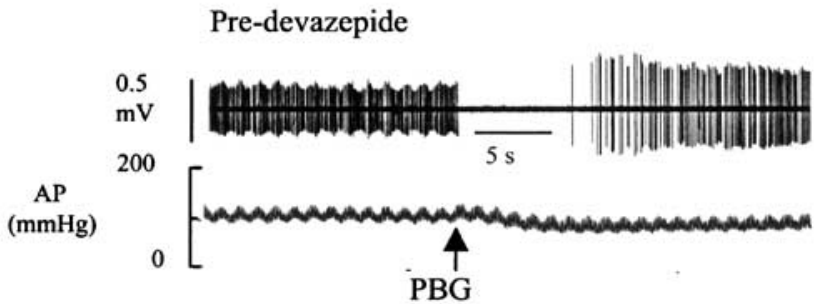

Post-devazepide

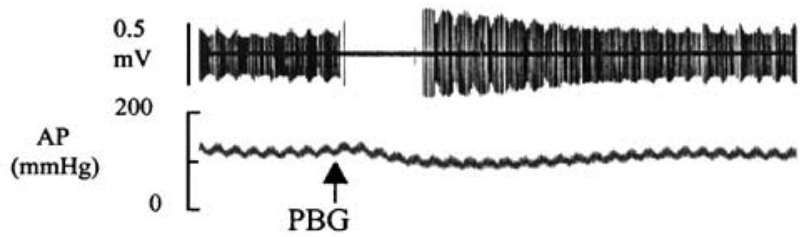

Figure 1 An RVLM presympathetic neuron and the effects of CCK $\left(4 \mu \mathrm{g} \mathrm{kg}^{-1}\right.$, i.v. $)$ and PBG $\left(10 \mu \mathrm{g} \mathrm{kg}^{-1}\right.$, i.v. $)$ before and after devazepide $\left(\mathrm{CCK}_{1}\right.$ receptor antagonist, $0.5 \mathrm{mg} \mathrm{kg}^{-1}$, i.v.). (a) Barosensitivity. The discharge of the neuron is slowed and briefly silenced by gradual elevation of arterial blood pressure (AP) produced by aortic occlusion (AOc). (b) Spinal projection. Spinal stimulation (arrow) elicits a constant latency neuronal spike (top two traces). Spinal stimulation applied within a critical period after arrival of a spontaneous spike results in collision (bottom trace). (c) Systemic injection of CCK reduces AP and inhibits the discharge of the neuron (upper panel). After devazepide administration, the responses to CCK administration are blocked (lower panel). (d) Systemic administration of PBG reduces AP and inhibits the discharge of the RVLM neuron (upper panel). After devazepide, the responses to PBG are essentially intact (lower panel). Note spike amplitude modulation in panels (a, $\mathrm{c}$ and d). 
Drugs

$\alpha$-Chloralose $\left(30 \mathrm{mg} \mathrm{ml}^{-1}\right.$; Sigma-Aldrich, Castle Hill, Australia) was dissolved in 2\% sodium tetraborate. PBG (Aldrich Chemical Co., Milwaukee, WIS, U.S.A.), MDL72222 ( $1 \alpha \mathrm{H}, 3 \alpha, 5 \alpha \mathrm{H}$-tropan-3-yl-3,5-dichloro-benzoate; Tocris, Bristol, U.K.) and CCK octapeptide (sulphated form; American Peptide Co., Sunnyvale, CA, U.S.A.) were dissolved in normal saline $\left(0.9 \% \mathrm{w} \mathrm{v}^{-1} \mathrm{NaCl}\right)$. PBG and CCK were injected in a volume of $0.1 \mathrm{ml} \mathrm{kg}^{-1}$. Devazepide (L-364,718; Merck Research Laboratories, Rahway, NJ, U.S.A.) was dissolved in dimethyl sulphoxide/polyethyleneglycol $400(9: 1)$ followed by $1: 1$ dilution with normal saline.

\section{Results}

Effect of devazepide on CCK- and PBG-induced cardiovascular responses and inhibition of RVLM presympathetic neurons

All 15 RVLM presympathetic neurons were recorded in 15 separate experiments and had the following properties: (i) barosensitivity (resting discharge was silenced or markedly inhibited by elevation of arterial blood pressure using gradual aortic occlusion), (ii) CCK sensitivity, (iii) PBG sensitivity, (iv) spinal projection (collision test positive; Figures $1 \mathrm{~b}$ and $3 \mathrm{~d}$ ) and (v) location (all neurons were found within $0-500 \mu \mathrm{m}$ of the caudal pole of the facial motor nucleus). Figure 1 depicts an example of an RVLM presympathetic vasomotor neuron and the influence of the $\mathrm{CCK}_{1}$ receptor antagonist devazepide on CCK- and PBG-induced inhibition of neuronal discharge. Note that the effects on neuronal discharge of arterial pressure elevation (Figure 1a), CCK administration (Figure 1c) and PBG administration (Figure 1d) are all accompanied by significant spike amplitude modulation. Prior to devazepide administration, systemic administration of CCK $\left(4 \mu \mathrm{g} \mathrm{kg}^{-1}\right.$, i.v.) produced a depressor response which is accompanied by a reduction, and subsequent silencing, of the discharge of the neuron (Figure 1c). After recovery, devazepide administration blocked the effect of readministration of CCK. In the same experiment, devazepide failed to affect the inhibitory response to PBG (Figure 1d).

Figure 2 depicts the influence of devazepide on the mean arterial blood pressure (MAP), heart (HR) rate and neuronal discharge responses to PBG (2 and $10 \mu \mathrm{g} \mathrm{kg}^{-1}$, i.v.) and CCK (1 and $4 \mu \mathrm{g} \mathrm{kg}^{-1}$, i.v.) for a group of five neurons recorded in five separate experiments. The mean spinal axonal conduction velocity for this group of neurons was $4.8 \pm 0.7 \mathrm{~m} \mathrm{~s}^{-1}(n=5)$. Devazepide had no significant effects on either the depressor, bradycardic or neuronal inhibitory effects of PBG $(n=5$ neurons). In contrast, devazepide blocked all of the effects of CCK on cardiovascular function and neuronal discharge $(P<0.05$ for all comparisons). Devazepide treatment did not significantly alter baseline MAP, HR or unit discharge (Table 1).

Effect of MDL72222 on CCK- and PBG-induced cardiovascular responses and inhibition of RVLM presympathetic neurons

Figure 3 depicts the influence of the selective $5-\mathrm{HT}_{3}$ receptor antagonist MDL72222 (0.1 $\mathrm{mg} \mathrm{kg}^{-1}$, i.v.) on the depressor and neuronal discharge effects of PBG $\left(10 \mu \mathrm{g} \mathrm{kg}^{-1}\right.$, i.v.) and CCK
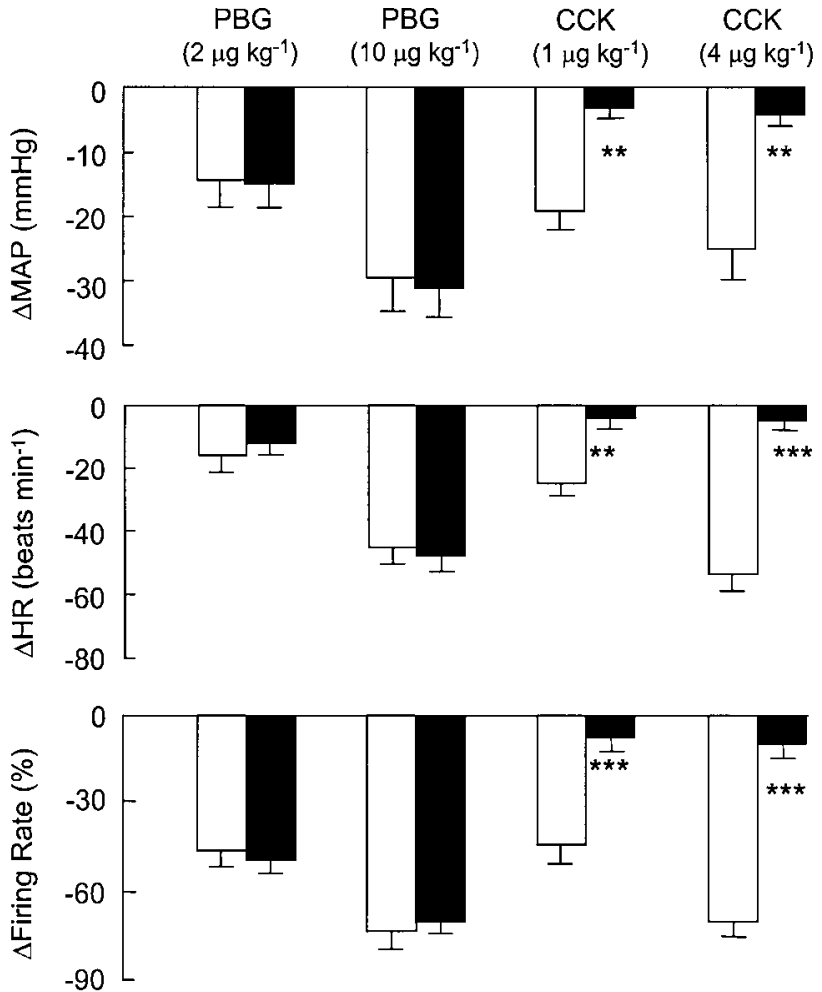

Figure 2 The effects of the $\mathrm{CCK}_{1}$ receptor antagonist devazepide $\left(0.5 \mathrm{mg} \mathrm{kg}^{-1}\right.$, i.v. $)$ on depressor, bradycardic and neuronal inhibitory responses to PBG ( 2 and $10 \mu \mathrm{g} \mathrm{kg}^{-1}$, i.v.) and CCK $\left(1\right.$ and $4 \mu \mathrm{g} \mathrm{kg}^{-1}$, i.v.). Open bars, predevazepide; filled bars, postdevazepide. All values are expressed as mean \pm s.e.m. for $n=5$ experiments (one neuron was studied per experiment). Abbreviations: $\Delta \mathrm{FR}$, change in neuronal firing rate; $\Delta \mathrm{HR}$, change in heart rate; $\triangle \mathrm{MAP}$, change in mean arterial blood pressure.

(4 $\mu \mathrm{g} \mathrm{kg}^{-1}$, i.v.). MDL72222 blocked the effects of PBG on arterial blood pressure and inhibition of RVLM neuronal discharge (Figure 3c). In addition, MDL72222 attenuated the effects of CCK on RVLM presympathetic neuronal discharge (Figure 3b).

Figure 4 depicts the effect of MDL72222 on the MAP, HR and neuronal discharge responses to PBG (2 and $10 \mu \mathrm{g} \mathrm{kg}^{-1}$, i.v.) and CCK ( 1 and $4 \mu \mathrm{g} \mathrm{kg}^{-1}$, i.v.) for a group of five neurons recorded in five separate experiments. The mean spinal axonal conduction velocity for this group of neurons was $4.4 \pm 0.6 \mathrm{~m} \mathrm{~s}^{-1}(n=5)$. MDL72222 significantly reduced the bradycardic and neuronal inhibitory effects of PBG $\left(2 \mu \mathrm{g} \mathrm{kg}^{-1}\right.$, i.v.) and the depressor, bradycardic and neuronal inhibitory effects of the higher dose of PBG $\left(10 \mu \mathrm{g} \mathrm{kg}^{-1}\right.$, i.v. $)(P<0.05$ for all comparisons; $n=5$ neurons). In addition, MDL72222 significantly attenuated the effects of CCK $\left(1 \mu \mathrm{g} \mathrm{kg}^{-1}\right.$, i.v. on neuronal discharge and all of the effects on cardiovascular function and neuronal discharge of the higher dose of CCK (4 $\mu \mathrm{g} \mathrm{kg}^{-1}$, i.v. $)(P<0.05$ for all comparisons). MDL72222 treatment did not significantly alter baseline MAP, HR or unit discharge (Table 1).

Effect of vehicle on CCK- and PBG-induced cardiovascular responses and inhibition of RVLM presympathetic actions

Figure 5 depicts the effects of vehicle administration on the MAP, HR and neuronal discharge responses to $\mathrm{PBG}$ 
a

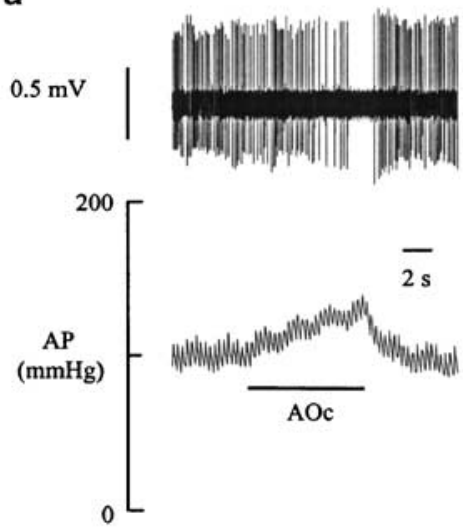

C

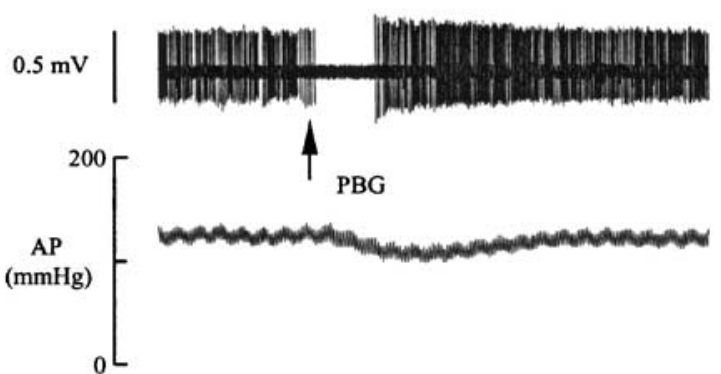

Post-MDL72222

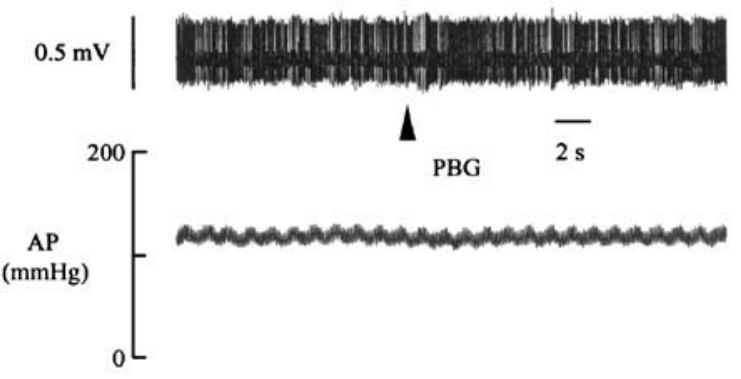

b
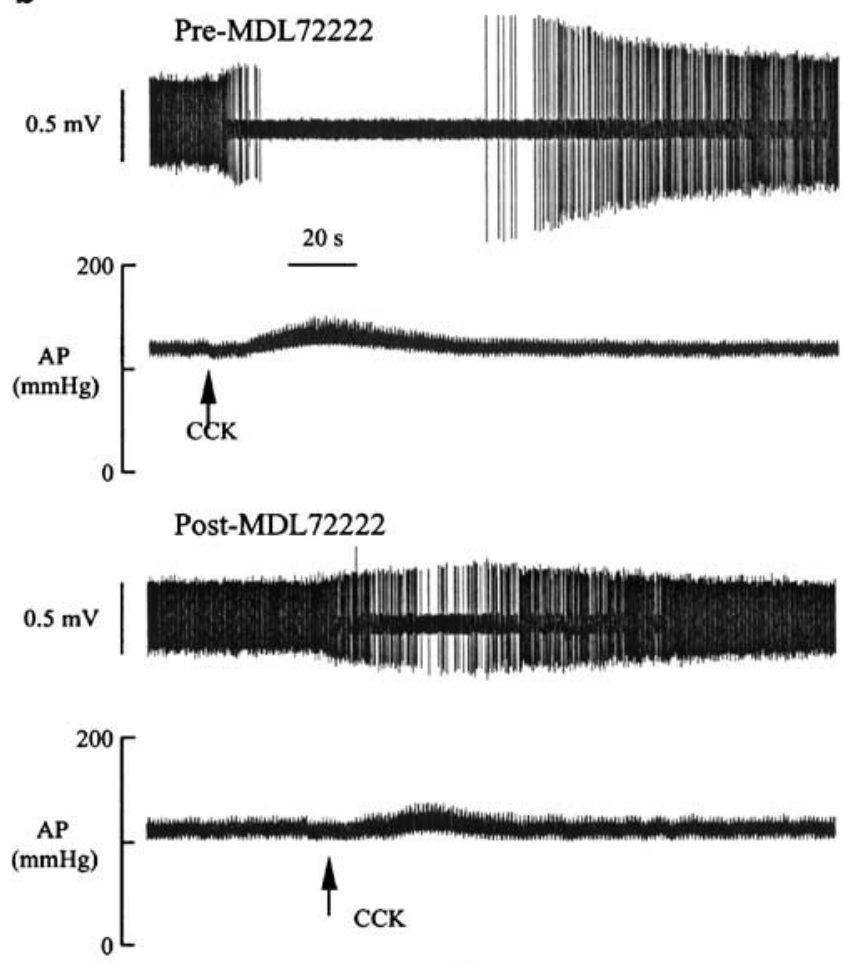

d

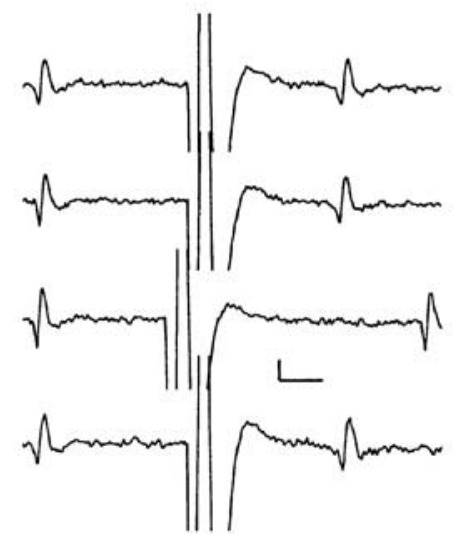

Figure 3 An RVLM presympathetic neuron and the effects of PBG $\left(10 \mu \mathrm{g} \mathrm{kg}^{-1}\right.$, i.v. $)$ and CCK $\left(4 \mu \mathrm{g} \mathrm{kg}^{-1}\right.$, i.v. $)$ before and after MDL72222 (5- $\mathrm{HT}_{3}$ receptor antagonist, $0.1 \mathrm{mg} \mathrm{kg}^{-1}$, i.v.). (a) Barosensitivity. The discharge of the neuron is slowed and eventually silenced by gradual elevation of arterial blood pressure (AP) produced by aortic occlusion (AOc). (b) Systemic administration of PBG reduces AP and inhibits the discharge of the RVLM neuron (upper panel). After MDL72222, the responses to PBG are blocked (lower panel). (c) Systemic injection of CCK reduces AP and inhibits the discharge of the neuron (upper panel). After MDL72222 administration, the responses to CCK administration are attenuated (lower panel). (d) Spinal projection. Spinal stimulation elicits a constant latency neuronal spike (top two traces and bottom trace). Spinal stimulation applied within a critical period after arrival of a spontaneous spike results in collision (third trace from top).

(10 $\mu \mathrm{g} \mathrm{kg}^{-1}$, i.v.) and $\mathrm{CCK}\left(4 \mu \mathrm{g} \mathrm{kg}^{-1}\right.$, i.v.) for a group of five neurons recorded in five separate experiments. The mean spinal axonal conduction velocity for this group of neurons was $4.5 \pm 0.4 \mathrm{~m} \mathrm{~s}^{-1}(n=5)$. Vehicle had no significant effect on the magnitude of the depressor, bradycardic or neuronal inhibitory effects of PBG or CCK. In the same animals, vehicle administration was followed by devazepide $\left(0.5 \mathrm{mg} \mathrm{kg}^{-1}\right.$, i.v. $)$. Devazepide blocked the effects of CCK $(P<0.05$ for all comparisons) but had no influence on the responses to $\mathrm{PBG}$ ( $P>0.05$ for all comparisons). Vehicle administration had no significant effect on MAP, HR or basal spike discharge rate (Table 1).

\section{Location of extracellular neuronal recording sites}

Histological identification of the Pontamine Sky blue ionophoretic deposits made at the recording sites indicated that all neurons were located in an area of the rostral ventrolateral medulla (Figure 6).

\section{Discussion}

Chemical stimulation of inhibitory vagal afferents has profound effects on regional sympathetic vasomotor outflow 

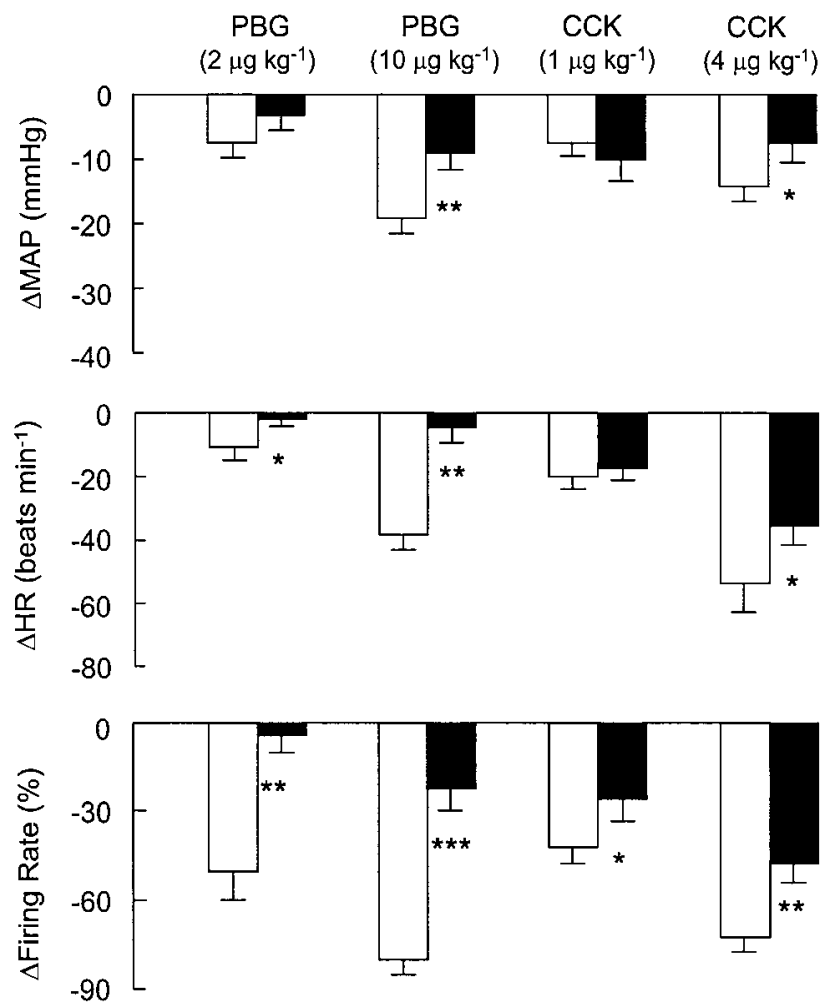

Figure 4 The effects of the 5-HT 3 receptor antagonist MDL72222 $\left(0.1 \mathrm{mg} \mathrm{kg}^{-1}\right.$, i.v.) on depressor, bradycardic and neuronal inhibitory responses to PBG (2 and $10 \mu \mathrm{g} \mathrm{kg}^{-1}$, i.v.) and CCK ( 1 and $4 \mu \mathrm{g} \mathrm{kg}^{-1}$, i.v.). Open bars, MDL72222; filled bars, post-MDL72222. All values are expressed as mean \pm s.e.m. for $n=5$ experiments (one neuron was studied per experiment). Abbreviations: $\Delta \mathrm{HR}$, changes in heart rate; $\triangle \mathrm{MAP}$, changes in mean arterial blood pressure.

and the discharge of RVLM presympathetic neurons (Verberne \& Guyenet, 1992; Veelken et al., 1997; Verberne et al., 2003). As demonstrated in a number of previous studies, 5$\mathrm{HT}_{3}$ receptor agonists such as PBG activate the von Bezold Jarisch reflex through stimulation of $5-\mathrm{HT}_{3}$ receptors on vagal afferents arising largely from the cardiopulmonary region (Evans et al., 1990; Kilpatrick et al., 1990; Bell et al., 1993). These agents also produce significant reduction of arterial blood pressure because they inhibit sympathetic vasomotor outflow to a number of different vascular beds and target organs (Veelken et al., 1990; Verberne \& Guyenet, 1992; Sevoz et al., 1996; Cao \& Morrison, 2000; Schreihofer \& Guyenet, 2000; Sartor \& Verberne, 2002). This property is reflected in the inhibitory actions of $5-\mathrm{HT}_{3}$ receptor agonists on the discharge of RVLM presympathetic neurons (Verberne \& Guyenet, 1992; Verberne et al., 1999). Thus, the majority of RVLM presympathetic neurons are inhibited by activation of cardiopulmonary $5-\mathrm{HT}_{3}$ receptors. It has been established that the central neurocircuitry that mediates the sympathoinhibitory actions of $5-\mathrm{HT}_{3}$ receptor agonists resembles that of the trisynaptic model proposed for the arterial baroreceptor vasomotor reflex (Verberne \& Guyenet, 1992; Verberne et al., 2003). This model proposes that RVLM presympathetic neurons are inhibited by activation of a population of GABAergic propriomedullary neurons in the caudal ventrolateral medulla. It remains to be established whether or not CCK-induced inhibition of RVLM presympathetic neurons proceeds via a similar mechanism.
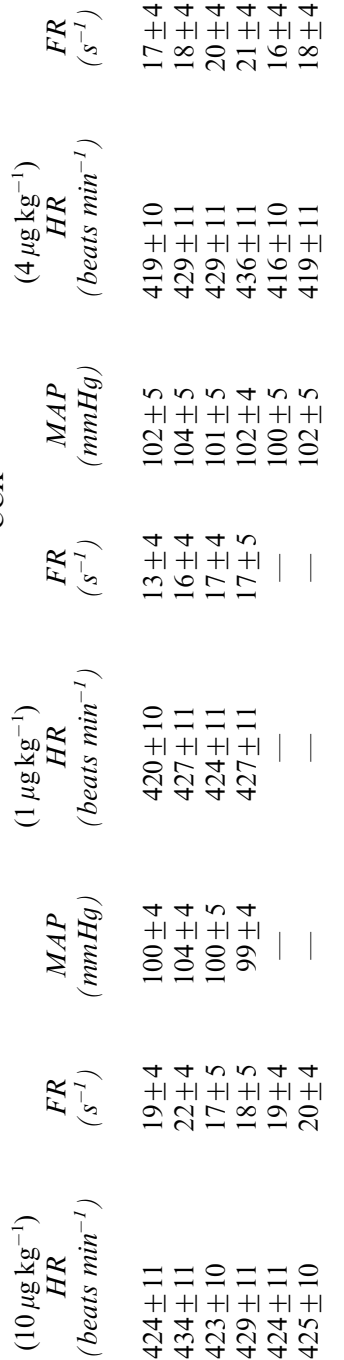

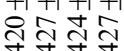

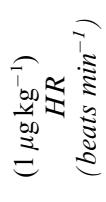

in $\ln \theta \sin$

공용ㅇㅇ

$\overleftarrow{U}$

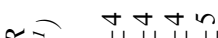

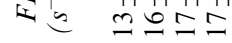

₹

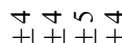

$8 \pm 82$

还证

$\lambda+\ln \theta+$

$4+1+1+1+1+10$

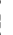



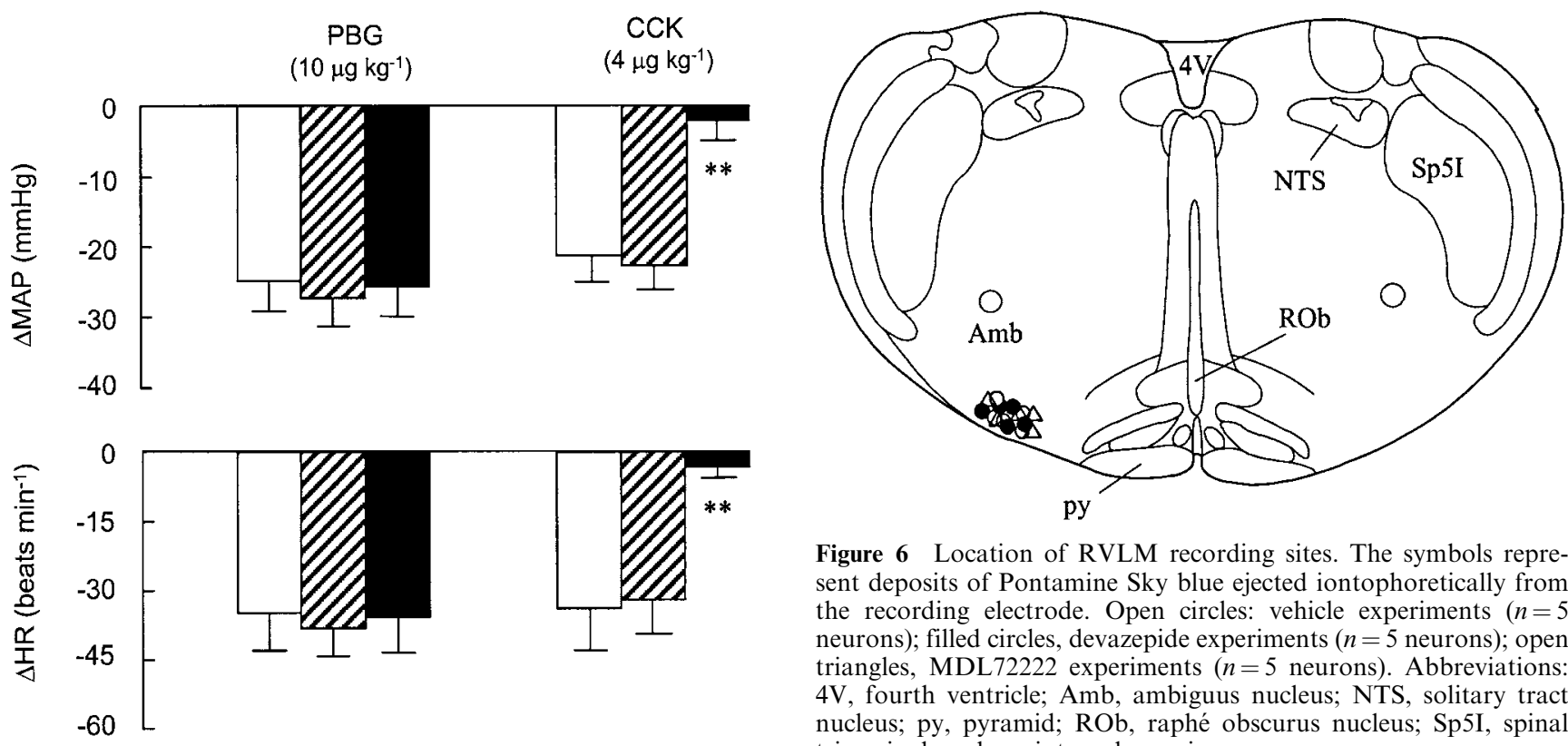

Figure 6 Location of RVLM recording sites. The symbols represent deposits of Pontamine Sky blue ejected iontophoretically from the recording electrode. Open circles: vehicle experiments $(n=5$ neurons); filled circles, devazepide experiments ( $n=5$ neurons); open triangles, MDL72222 experiments ( $n=5$ neurons). Abbreviations: $4 \mathrm{~V}$, fourth ventricle; Amb, ambiguus nucleus; NTS, solitary tract nucleus; py, pyramid; ROb, raphé obscurus nucleus; Sp5I, spinal trigeminal nucleus, interpolar region.

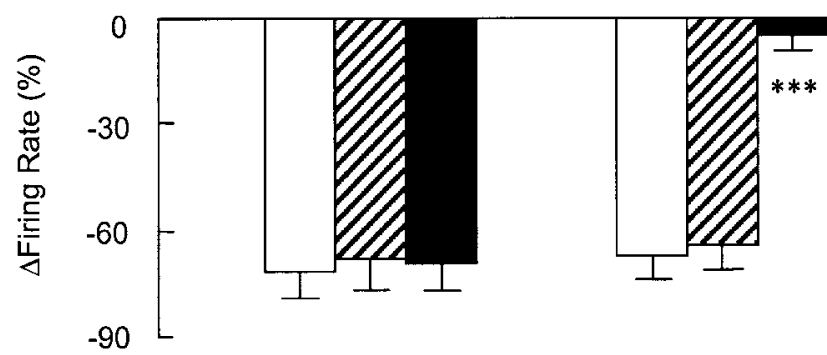

Figure 5 Effects of vehicle and devazepide on MAP, HR, and firing rate (FR) responses to systemic administration of $\mathrm{PBG}$ $\left(10 \mu \mathrm{g} \mathrm{kg}^{-1}\right)$ and CCK $\left(4 \mu \mathrm{g} \mathrm{kg}^{-1}\right)$. Open bars, prevehicle; hatched bars, postvehicle. Devazepide $\left(0.5 \mathrm{mg} \mathrm{kg}^{-1}\right.$ i.v.; filled bars) abolished CCK-induced decreases in MAP, HR and FR but vehicle did not alter any parameter. Vehicle consisted of dimethyl sulphoxide $(45 \%)$, polyethyleneglycol $(5 \%)$, and saline $\left(0.9 \% \mathrm{NaCl} \mathrm{w} \mathrm{v} \mathrm{v}^{-1}\right.$; $50 \%)$. $\triangle \mathrm{MAP}, \triangle \mathrm{HR}$ and $\Delta \mathrm{FR}$ are changes relative to preinjection levels. Values are means \pm s.e.m. for $n=5$ experiments (one neuron was studied per experiment). ${ }^{* *} P<0.01 ;{ }^{*} * P<0.001$.

A limitation of the present study is that the agonists PBG, CCK and the antagonists devazepide and MDL72222 were administered systemically. However, several lines of evidence suggest that these drugs are acting at peripheral sites. Firstly, we have previously shown that the actions of CCK on arterial blood pressure and splanchnic sympathetic nerve discharge are dependent on intact vagal afferents (Sartor \& Verberne, 2002). Similarly, the sympathoinhibitory effects of PBG are sensitive to vagal section (Mohr et al., 1987; Evans et al., 1990). Secondly, $\mathrm{CCK}_{1}$ receptors and $5-\mathrm{HT}_{3}$ receptors are found on the cell bodies of vagal afferents and are transported to peripheral sites by axonal transport mechanisms (Zarbin et al., 1981; Kilpatrick et al., 1990; Lin \& Miller, 1992; Corp et al., 1993; Uneyama et al., 2002). Taken together, these observations suggest that the antagonists devazepide and MDL72222 block the actions of CCK and PBG by blocking the respective receptors located on vagal afferent neurones.

In this study, we have confirmed and extended the results of a previously published investigation which indicated that CCK inhibits the discharge of a subpopulation of RVLM presym-

pathetic neurons through activation of $\mathrm{CCK}_{1}$ receptors (Sartor $\&$ Verberne, 2002). In addition, we have demonstrated that the inhibitory action of $\mathrm{CCK}_{1}$ receptor activation on RVLM presympathetic neuronal discharge is dependent, at least in part, on the activation of $5-\mathrm{HT}_{3}$ receptors. Several studies have demonstrated that some of the actions of CCK are dependent on activation of 5- $\mathrm{HT}_{3}$ receptors (Blackshaw \& Grundy, 1993; Daughters et al., 2001). This phenomenon is by no means universal since the actions of agonists at these receptors on mesenteric vagal afferents are largely, but not completely, independent (Hillsley \& Grundy, 1998). On the other hand, a preliminary report suggests that a proportion of nodose ganglion neurons respond to both $\mathrm{CCK}_{1}$ and $5-\mathrm{HT}_{3}$ receptor stimulation (Simasko et al., 2002). These observations support those made by previous investigators that some of the actions of CCK are dependent on release of 5-HT. A strong possibility is that CCK releases 5-HT from gastrointestinal enterochromaffin cells (Chey \& Chang, 2001).

A number of other conclusions may be drawn from the results of the present study. Firstly, CCK does not simply mimic 5-HT to produce inhibition of RVLM presympathetic neuronal discharge. CCK selectively inhibits a subpopulation of RVLM presympathetic neurons, which belong to a group which tend to have fast-conducting spinal axons and which are generally phenotypically nonadrenergic neurons (Schreihofer \& Guyenet, 1997; Sartor \& Verberne, 2002). In this respect, it is apparent that CCK does not activate the von Bezold Jarisch reflex. Secondly, the inhibitory actions of CCK on RVLM neuronal discharge were, in part, dependent on 5-HT since the effects of CCK were attenuated by the 5-HT antagonist MDL-72222. In contrast, the effects of PBG were insensitive to devazepide, a selective $\mathrm{CCK}_{1}$ receptor antagonist. CCK may activate a subpopulation of abdominal vagal afferents, which send inhibitory signals to some RVLM presympathetic neurons via an unidentified intramedullary pathway.

It is also of interest to compare the bradycardic effects of PBG and CCK. PBG elicits a reflex bradycardia which is a 
component of activation of the von Bezold - Jarisch reflex (Verberne et al., 1987). In contrast, CCK-induced bradycardia is not influenced by vagotomy (Sartor \& Verberne, 2002) and can be demonstrated in vitro in the isolated perfused heart (Marker \& Roberts, 1988). Although it remains a possibility that the direct negative chronotropic actions of CCK mask the reflex actions of the peptide, it appears that CCK-induced bradycardia is not mediated by a vagovagal reflex.

Upon careful inspection of the effects of CCK and PBG on RVLM neuronal discharge, it is apparent that these agents reduce neuronal discharge rate and simultaneously increase the magnitude of the extracellularly recorded neuronal spike. This phenomenon of spike amplitude modulation also occurs when the baroreceptor pathway is activated. Spike amplitude modulation has been previously attributed to activation of a GABAergic inhibitory input, which results in a decrease in neuronal input resistance (Sun \& Guyenet, 1985). GABAergic mechanisms have been implicated in both baroreceptormediated inhibition and von Bezold - Jarisch reflex-mediated

\section{References}

BELL, L.B., O'HAGAN, K.P. \& CLIFFORD, P.S. (1993). Cardiac but not pulmonary receptors mediate depressor response to IV phenyl biguanide in conscious rabbits. Am. J. Physiol., 264, R1050R 1057.

BERTHOUD, H.R. \& NEUHUBER, W.L. (2000). Functional and chemical anatomy of the afferent vagal system. Autonom. Neurosci., 85, $1-17$.

BLACKSHAW, L.A. \& GRUNDY, D. (1990). Effects of cholecystokinin (CCK-8) on two classes of gastroduodenal vagal afferent fibre. $J$. Auton. Nerv. Syst., 31, 191-201.

BLACKSHAW, L.A. \& GRUNDY, D. (1993). Effects of 5-hydroxytryptamine on discharge of vagal mucosal afferent fibres from the upper gastrointestinal tract of the ferret. J. Auton. Nerv. Syst., 45, $41-50$.

BROWN, D.L. \& GUYENET, P.G. (1985). Electrophysiological study of cardiovascular neurons in the rostral ventrolateral medulla in rats. Circ. Res., 56, $359-369$.

CAO, W.H. \& MORRISON, S.F. (2000). Responses of adrenal sympathetic preganglionic neurons to stimulation of cardiopulmonary receptors. Brain Res., 887, $46-52$.

CHEY, W.Y. \& CHANG, T.M. (2001). Neural hormonal regulation of exocrine pancreatic secretion. Pancreatology, 1, 320-335.

CORP, E.S., MCQUADE, J., MORAN, T.H. \& SMITH, G.P. (1993). Characterization of type A and type B CCK receptor binding sites in rat vagus nerve. Brain Res., 623, $161-166$.

DAUGHTERS, R.S., HOFBAUER, R.D., GROSSMAN, A.W., MARSHALL, A.-M., BROWN, E.M., HARTMAN, B.K. \& FARIS, P.L. (2001). Ondansetron attenuates CCK induced satiety and c-fos labeling in the dorsal medulla. Peptides, 22, 1331-1338.

EVANS, R.G., LUDBROOK, J. \& MICHALICEK, J. (1990). Characteristics of cardiovascular reflexes originating from 5-HT3 receptors in the heart and lungs of unanaesthetized rabbits. Clin. Exp. Pharmacol Physiol., 17, $665-679$.

FOZARD, J.R. (1984). MDL 72222: a potent and highly selective antagonist at neuronal 5-hydroxytryptamine receptors. NaunynSchmiedeberg's Arch. Pharmacol., 326, 36-44.

GUYENET, P.O., FILTZ, T.M. \& DONALDSON, S.R. (1987). Role of excitatory amino acids in rat vagal and sympathetic baroreflexes. Brain Res., 407, 272 - 284.

HILLSLEY, K. \& GRUNDY, D. (1998). Serotonin and cholecystokinin activate different populations of rat mesenteric vagal afferents. Neurosci. Lett., 255, $63-66$.

KILPATRICK, G.J., BUTLER, A., BURRIDGE, J. \& OXFORD, A.W. (1990). 1-(m-chlorophenyl)-biguanide, a potent high affinity 5-HT3 receptor agonist. Eur. J. Pharmacol., 182, 193-197.

KUROSAWA, M., UVNAS-MOBERG, K., MIYASAKA, K. \& LUNDEBERG, T. (1997). Interleukin-1 increases activity of the gastric vagal inhibition of RVLM presympathetic vasomotor neurons (Sun \& Guyenet, 1985; Verberne \& Guyenet, 1992). This raises the possibility that CCK-induced inhibition of RVLM presympathetic vasomotor neurons is mediated by activation of a GABAergic input.

In conclusion, the inhibitory effect of CCK on the discharge rate of a subpopulation of RVLM presympathetic vasomotor neurons is dependent on $\mathrm{CCK}_{1}$ receptors and also, in part, on $5-\mathrm{HT}_{3}$ receptors. In addition, $\mathrm{CCK}$ does not activate the von Bezold - Jarisch reflex. Instead, it has selective effects on RVLM presympathetic neuronal discharge, which may be mediated by an unidentified propriomedullary GABAergic pathway.

This work was supported by grants from the National Health and Medical Research Foundation of Australia (NH\&MRC) and the Austin Hospital Medical Research Foundation. A.J.M.V. is a Senior Research Fellow of the NH\&MRC. afferent nerve partly via stimulation of type A CCK receptor in anesthetized rats. J. Auton. Nerv. Syst., 62, $72-78$.

LIN, C.W. \& MILLER, T.R. (1992). Both CCK-A and CCK-B/gastrin receptors are present on rabbit vagus nerve. Am. J. Physiol., 263, R591 - R595.

LOUIE, D.S., LIANG, J.P. \& OWYANG, C. (1988). Characterization of a new CCK antagonist, L364,718: in vitro and in vivo studies. Am. J. Physiol., 255, G261 - G266.

MARKER, J.D. \& ROBERTS, M.L. (1988). Chronotropic actions of cholecystokinin octapeptide on the rat heart. Regul. Pept., 20, 251 259.

MOHR, B., BOM, A.H., KAUMANN, A.J. \& THAMER, V. (1987). Reflex inhibition of efferent renal sympathetic nerve activity by 5 hydroxytryptamine and nicotine is elicited by different epicardial receptors. Pflugers Arch., 409, $145-151$.

PAXINOS, G. \& WATSON, C. (1997). The Rat Brain in Stereotaxic Coordinates. Sydney: Academic Press.

SARTOR, D.M. \& VERBERNE, A.J.M. (2002). Cholecystokinin selectively affects presympathetic vasomotor neurons and sympathetic vasomotor outflow. Am J Physiol., 282, R1174-R1184.

SCHREIHOFER, A.M. \& GUYENET, P.G. (1997). Identification of $\mathrm{C} 1$ presympathetic neurons in rat rostral ventrolateral medulla by juxtacellular labeling in vivo. J. Comp. Neurol., $\mathbf{3 8 7}$, $524-536$.

SCHREIHOFER, A.M.\& GUYENET, P.G. (2000). Sympathetic reflexes after depletion of bulbospinal catecholaminergic neurons with antiD beta H-saporin. Am. J. Physiol., 279, R729 - R742.

SCROGIN, K.E., VEELKEN, R. \& JOHNSON, A.K. (1998). Central methysergide prevents renal sympathoinhibition and bradycardia during hypotensive hemorrhage. Am. J. Physiol., 43, H43- H51.

SEVOZ, C., NOSJEAN, A., CALLERA, J.C., MACHADO, B., HAMON, M. \& LAGUZZI, R. (1996). Stimulation of 5-HT3 receptors in the NTS inhibits the cardiac Bezold - Jarisch reflex response. Am. J. Physiol., 40, $\mathrm{H} 80$ - $\mathrm{H} 87$.

SIMASKO, S.M., PETERS, J.H., WIENS, J. \& RITTER, R.C. (2002). Coactivation of nodose ganglion neurons by cholecystokinin and serotonin. Program No. 76.11. 2002 Abstract Viewer/Itinerary Planner, Washington, DC: Society for Neuroscience, 2002. CD-ROM.

SUN, M.K. \& GUYENET, P.G. (1985). GABA-mediated baroreceptor inhibition of medullary vasomotor neurones. Am. J. Physiol., 249, R672 - R680.

UNEYAMA, H., NIIJIMA, A., TANAKA, T. \& TORII, K. (2002). Receptor subtype specific activation of the rat gastric vagal afferent fibers to serotonin. Life Sci., 72, 415-423.

VAYSSETTES-COURCHAY, C., BOUYSSET, F., LAUBIE, M. \& VERBEUREN, T.J. (1997). Central integration of the Bezold - Jarish reflex in the cat. Brain Res., 744, $272-278$. 
VEELKEN, R., LEONARD, M., STETTER, A., HILGERS, K.F., MANN, J.F.E., REEH, P.W., GEIGER, H. \& LUFT, F.C. (1997). Pulmonary serotonin 5-HT3-sensitive afferent fibers modulate renal sympathetic nerve activity in rats. Am. J. Physiol., 41, H979- H986.

VEELKEN, R., SAWIN, L.L. \& DIBONA, G.F. (1990). Epicardial serotonin receptors in circulatory control in conscious Sprague Dawley rats. Am. J. Physiol., 258, H466- H472.

VERBERNE, A.J.M. \& GUYENET, P.G. (1992). Medullary pathway of the Bezold - Jarisch reflex in the rat. Am J Physiol., 263, R1195R1202.

VERBERNE, A.J.M., LEWIS, S.J., JARROTT, B. \& LOUIS, W.J. (1987). Bezold - Jarisch reflex is inhibited by excitotoxin-induced destruction of vagal primary afferent neurons. Eur. J. Pharmacol., 139, $365-367$.

VERbERNE, A.J.M., SAITA, M. \& SARTOR, D.M. (2003). Chemical stimulation of vagal afferent neurons and sympathetic vasomotor tone. Brain Res. Rev. 41, $288-305$.

VERBERNE, A.J.M., STORNETTA, R.L. \& GUYENET, P.G. (1999). Properties of $\mathrm{Cl}$ and other ventrolateral medullary neurones with hypothalamic projections in the rat. J. Physiol. (London), 517, $477-494$.

WIDDOP, R.E., KRSTEW, E., MERCER, L.D., CARLBERG, M., BEART, P.M. \& JARROTT, B. (1994). Electrophysiological and autoradiographical evidence for cholecystokinin A receptors on rat isolated nodose ganglia. J. Auton. Nerv. Syst., 46, 65-73.

YOSHIDA-YONEDA, E., TJ, O.L., WEI, J.Y., VIGNA, S.R. \& TACHE Y. (1996). Peripheral bombesin induces gastric vagal afferent activation in rats. Am. J. Physiol., 271, R1584-R1593.

ZARBIN, M.A., WAMSLEY, J.K., INNIS, R.B. \& KUHAR, M.J. (1981) Cholecystokinin receptors: presence and axonal flow in the rat vagus nerve. Life Sci., 29, 697 - 705.

(Received December 24, 2002

Revised February 6, 2003

Accepted February 19, 2003) 